\title{
Employment Equity and Access to Social
for Illegalized Immigrants: An Inclusive Approach That Also Makes Economic Sense
}

Charity-Ann Hannan

RCIS Working Paper No. 2013/1

September 2013

SERIES EDITOR

Harald Bauder

Ryerson Centre for Immigration \& Settlement Ryerson University

Jorgenson Hall, 620

350 Victoria Street, Toronto, ON M5B2K3

http://www.ryerson.ca/rcis 
RCIS Working Paper

No. $2013 / 1$

\title{
Employment Equity and Access to Social Welfare for Illegalized Immigrants:
}

\author{
An Inclusive Approach That Also Makes Economic Sense
}

\author{
Charity-Ann Hannan \\ Ryerson University
}

RCIS Working Papers present scholarly research of all disciplines on issues related to immigration and settlement. The purpose is to stimulate discussion and collect feedback. The views expressed by the author(s) do not necessarily reflect those of RCIS. For a complete list of RCIS publications, visit www.ryerson.ca/rcis

ISSN: 1929-9915

This RCIS Working Paper was presented at the 2013 RCIS conference "Immigration and Settlement: Precarious Futures?" held at Ryerson University, May 15-17, 2013. This publication and the conference received funding from the Social Sciences and Humanities Research Council of Canada. 


\section{Preface}

The opportunity to write this research paper arose from a fellowship supported by RCIS (Ryerson Centre for Immigration and Settlement), $\mathrm{MCl}$ (Ministry of Citizenship \& Immigration), and Ryerson University's Policy Studies PhD Program. One of the main goals of the fellowship is to engage students in scholarly research and creative activities. During Summer 2012, this fellowship enabled me to collect, synthesize, and analyze the global English-language literature to answer the initial question posed by $\mathrm{MCl}$ : what are the effects of undocumented immigrants on the labour market? While reviewing the literature I developed the following, more precise set of questions:

- What are the factors affecting illegalized immigrants' labour market outcomes?

- What are the effects of illegalized immigrants on the labour market outcomes of native-born workers?

- What are the effects of illegalized immigrants on social welfare systems?

- What are the effects of illegalized immigrants on the organizations they work for?

\section{Abstract}

The global English-language literature on the effects of illegalized migrants on the labour market is heavily influenced by American studies. While many studies have examined the lived experiences of illegalized immigrants in general, comparatively few have examined the effect of illegalized immigrants on labour markets in a Canadian and European context. The literature review reveals four main findings:

1. Increasingly restrictive policies towards immigrants and employers have adversely affected illegalized immigrants' labour market outcomes during the past three decades.

2. Illegalized immigrants have positively affected the earnings of native-born skilled workers and negatively affect the earnings of native-born unskilled workers. The effect of illegalized immigrants on the employment rates of native-borns has been negligible.

3. Illegalized immigrants have positively affected the national-level social welfare system. The findings for illegalized immigrants' effects on state/provincial and local-level social welfare systems are mixed.

4. Organizations have benefitted from employing illegalized immigrants whose illegality renders them vulnerable to exploitation and unable to make demands for equitable remuneration.

While a direct link between increasingly restrictive policies towards immigrants, their labour market outcomes, and their utilization of social welfare systems has not yet been examined in Canada, findings from the U.S. and several European countries can inform recommendations that may be useful for industrialized countries.

First, findings from these studies indicate that all levels of government should work together to create policies that include illegalized immigrants as equal members of society, rather than maintain the current system(s) that illegalizes them. This includes providing illegalized immigrants with equitable access to social welfare at federal, 
state/provincial, and municipal levels. Various Solidarity City movements in Canada, the U.S., and Europe could be examined, and the best practices applied to state/provincial and federal levels to begin this process.

Second, all levels of government should work together to create a policy framework that mandates employers to provide equitable remuneration to illegalized immigrants. This policy should also hold employers accountable for achieving these goals. Canada's current Employment Equity Act (1995) and various state/provincial level Equality \& Human Rights Legislations could be amended to protect illegalized immigrants from exploitation.

Third, until illegalized immigrants are no longer exploited based on their illegality, all levels of government should fund community-based organizations to provide them with the resources they need to facilitate their inclusion into the society in which they work. By brokering relationships between exploited illegalized immigrant workers and existing labour market institutions, community organizations like the Latino Organization of the Southwest's (LOS) Economic Development Centre (EDC), located in Chicago, USA, can help improve the quality of illegalized immigrants' jobs and thus support more positive labour market outcomes.

\section{Introduction}

During the past three to four decades, competition between corporations has increased as a result of globalization. During the same time period, increasingly restrictive policies towards immigrants have created a population that is vulnerable to exploitationillegalized immigrants ${ }^{1}$ (Castles, 2004; De Genova, 2002; Gentsch \& Massey, 2012; Goldring \& Landolt, 2011; Gomberg-Munoz \& Nussbaum-Barberena, 2011; McDowell et al., 2009; Morales, 1983-1984; Paraskevopoulou, 2010; Wright, 2003). As employers are also accountable to increasingly restrictive hiring policies, this has created a labour market in which employers are able to actively exploit illegalized immigrants, benefiting and profiting from differentially remunerating this newly constructed group (Davila \& Pagan, 1997; Donato et al., 1992; Fry et al., 1995; Goldring \& Landolt, 2012; GombergMunoz \& Nussbaum-Barberena, 2011; Koussoudji \& Cobb-Clark, 1996; Kossoudji \& Cobb-Clark, 2000; Massey \& Bartley, 2005; Orrenius \& Zavodney, 2012; Phillips \& Massey, 1999; Powers et al., 1998; Rivera-Batiz, 1999; Taylor, 1992). This exploitation not only has implications for illegalized immigrants' families, health, and housing due to lower wages, but also the labour markets they participate in due to occupational immobility (Bernhard et al., 2007; Burgers, 1998; Gonzales, 2011; Grasmuck, 1984; Magalhaes et al., 2010; Miklavcic, 2011; Simich et al., 2007; Suarez-Orozco et al., 2011; Villarejo, 2003).

In an effort to stay profitable during periods of increasing competition, employers have historically implemented a "divide and conquer" approach to management based on a variety of identity markers including gender/sex, ethno-racial, aboriginality, ability, age, and/or nationality. Illustrating this approach, the Dunsmuirs' coal mining company,

\footnotetext{
${ }^{1}$ The term 'illegal migrants' arose for the first time in Canada during the 1960s-1970s (Khandor et al., 2004; Marsden, 2012)
} 
which was the largest employer of Chinese labour in British Columbia during the late 1800 s, began to pay Chinese workers half as much as white miners when the market became increasingly competitive (Reksten, 1991). Finding an opportunity in this for themselves, white miners began to sub-contract Chinese workers to help them with their workloads. "One miner went on holidays and left his Chinaman to do all the mining and still managed to clear almost three dollars a day" (Reksten, 1991: 88). Yet as the Chinese population continued to grow, white miners began to perceive them as a threat to their employment, and demands for "Oriental Exclusion" emerged. By the 1870s, Associations and Leagues formed that pushed for "the mutual protection of the working classes of British Columbia against the influx of Chinese, and the use of legitimate means for suppression of immigration" (Reksten, 1991: 87). Beginning in 1886, Association and League rallies often turned into riots with mobs attacking Chinatowns and Japanese districts (Reksten, 1991; Roy, 1989). These white workers directed their anger towards their Chinese co-workers instead of engaging with them in a unified effort to hold their employer accountable for differentially remunerating employees based on ethno-racial identity, which allowed the harmful actions of their employers to go unnoticed. During this time, the owner of the company, Robert Dunsmuir, entered politics to oppose the advancement of exclusionary immigration policies towards Chinese and Japanese immigrants in order to ensure a continued supply of exploitable labour for his mines (Reksten, 1991).

In more recent history, corporations in Canada have effectively lobbied the government to create programs to bring in Temporary Foreign Workers (TFWs), ${ }^{2}$ including agricultural workers, live-in caregivers, low-skilled occupations, and highskilled occupations. Although TFW numbers fluctuated from 1973 and 2000, they steadily increased from 89,000 in 2000 to slightly over 300,000 in 2010 (Foster, 2012; Sharma, 2006). While employers have argued that they require TFWs to fill labour market shortages (McQuillon, 2013), critics have argued that employers demanded TFWs following the economic crises of the 1970s and 80s because their "temporary" identity makes them vulnerable to exploitation (Sharma, 2006; Morales, 1983-1984). For example, studies have found TFWs to "involve being tied to the importing employer; low wages, often below the minimum, and long hours with no overtime pay; dangerous working conditions, crowded and unhealthy accommodation; denial of access to public healthcare and employment insurance, despite paying into the programmes; and being virtually held captive by employers or contractors who seize identification documents" (Walia, 2012: 72). Despite these conditions, however, native-borns who viewed TFWs as threats their employment security forced the Royal Bank of Canada (RBC) to dismiss the TFWs they recently brought in from India, rather than unite with them in an effort to demand equitable remuneration for their work (Tomlinson, 2013).

Resembling the experiences of Chinese coal miners during the late 1800 s to early 1900s, and TFWs in the late 20th and early 21st century, illegalized immigrants today have been perceived as a threat, and are accused of adversely affecting labour

\footnotetext{
${ }^{2}$ The TFW program evolved out of Canada's 1973 Immigrant Employment Authorization Program (NIEAP), which established a new class of immigrant (temporary resident) tied specifically to nonpermanent employment (Foster, 2012).
} 
markets, the economic security of hard-working native-borns, and the social welfare systems of countries they reside in (Alcoba, 2013; Blondell, 2008; Jimenez, 2003). Yet numerous studies are available today that disprove these allegations. In fact, a review of the literature shows that illegalized immigrants could contribute more to labour markets if they had formal legal status. Instead, employers are profiting by hiring this group of workers and differentially remunerating them based on their illegality-a newly constructed identity marker used to justify exploitation. Furthermore, by causing conflict between illegalized immigrants and native-born workers, employers are benefiting by diverting attention from issues of wages, organizing rights, and health and safety standards (Allegro, 2010).

Organized into eight sections, the following section of this paper defines "illegalized immigrants" and introduces the approaches that researchers have taken to studying the effects of illegalized immigrants on labour markets. The factors found to effect illegalized immigrants' labour market outcomes, the effects of illegalized immigrants on the labour market outcomes of native-borns, and the effects of illegalized immigrants on social welfare systems are discussed in sections three, four, and five, respectively. Section six discusses the effects of illegalized migrants on the organizations they work for, which is followed by section seven, the discussion and recommendations, and finally section eight, the conclusion.

\section{Illegalized Migrants}

Although people were mobile long before national borders were constructed, individuals who do not have the documentation to reside in a country are commonly referred to as undocumented, unauthorized, illegal, clandestine, alien, irregular, and/or sans-papiers (Bauder, 2013; Lyon, 2003-2004). In this paper, I support Bauder's (2013) suggestion to describe people who do not have the documentation to reside in a country as illegalized immigrants to draw attention to the processes that make immigrants illegal. As scholars have described, there are several pathways though which immigrants become illegalized including:

- Crossing a border without the required documentation;

- Crossing a border legally and subsequently falling out of status while in the country. This can happen if a tourist, student, or worker stays in the country beyond the visitor, student, or work visa/permit expiry date; and

- Crossing a border with a refugee claim that has been subsequently rejected (Bauder, 2013; Goldring et al., 2007; Goldring \& Landolt, 2011, 2012; Marsden, 2012; Standing Committee on Citizenship and Immigration, 2009).

Compared to the USA, where most immigrants become illegal when they cross the border from Mexico into the USA without the required documentation (e.g., work, student, tourist permits), most immigrants in Canada become illegal when they stay in the country beyond the expiry date identified on their tourist, student, or work permit (Bauder, 2013; Goldring \& Landolt, 2012).

More broadly, Canadian researchers have conceptualized illegalized immigrants as members of a "precarious" legal status category (Goldring et al., 2007; Goldring \& 
Landolt, 2011, 2012). Compared to the American literature that focuses on the dichotomous illegal/legal immigrant category, "precarity" enables researchers to focus on the relationship between migration status, legal trajectories, and job quality (Goldring et al., 2007). Goldring \& Landolt (2012) have found that job quality is negatively associated with immigrants who have precarious status (compared to immigrants whose status remained secure), however, their research also indicates that employers have used immigrants' illegality as a marker of discrimination. ${ }^{3}$ As this status adversely affects the labour market outcomes of illegalized immigrants, this paper therefore takes the perspective that the legal/illegal dichotomy is one of several important identity markers (including permanent worker/TFW and permanent worker/refugee) that researchers should investigate under the "precarity" umbrella in the Canadian context.

Similar to many other countries, Canada does not have a tracking system in place to gauge the number of illegalized immigrants in the country. Three different estimates between 2003 and 2008 have determined that the number of illegalized immigrants will to reach an all-time high in 2015 when many four-year Temporary Foreign Worker (TFW) work permits are set to expire (Keung, 2013). A 2003 estimate suggested that the number was 36,000 (Jimenez, 2003). A 2007 estimate suggested a range of 50,000 to 200,000, with half of all illegalized immigrant workers residing in Toronto (Khandor et al., 2004). In 2008, Citizenship and Immigration Canada reported 80,000 to 500,000 unauthorized immigrants in Canada (Linklater, 2008). These estimates are much larger for the U.S., with 11.1 million unauthorized immigrants living in the country in 2012 (Passel \& Cohen, 2012).

To determine the effect of illegalized immigrants on labour markets and social welfare systems, researchers have examined the link between illegalized immigrants and their labour market outcomes including earnings and occupational mobility, as well as the factors affecting these outcomes including gender, education, work experience, social networks, illegality, and policies related to illegal status. Studies have also examined the effect of illegalized immigrants' labour market participation on the labour market outcomes of native-borns. To determine illegalized immigrants' effect on social welfare systems, researchers have estimated their income tax contributions compared to their utilization of the social welfare. Employing different theories to shed light on their findings, including neo-classical economic theory, human capital theory, and labour market segmentation theory, the policy recommendations from these studies vary considerably.

\section{The Factors Affecting Illegalized Migrants' Labour Market Outcomes Earnings} Research findings indicate that illegalized immigrants may not have earned significantly less than immigrants during the early 1980s, although this is certainly not the case today. For example, based on data collected in 1981 (Grasmuck, 1984) and data

\footnotetext{
${ }^{3}$ Further supporting the importance of considering the effects of illegality on the immigrant experience, a Report of the Standing Committee on Citizenship and Immigration argued that while TFW and non-status workers share non-permanent status and vulnerability to abuse, they have different stories of entry into Canada, different legal statuses, and thus different opportunities for social and economic participation in Canadian life (House of Commons, 2009).
} 
collected between 1982 and 1983 (Massey, 1987), there was not a statistically significant earnings difference between undocumented and documented immigrants. In fact, Grasmuck's (1984) analysis indicated gender status to be a greater determinant of low wages than legal status. However, studies that analyzed data collected after the Immigration Control and Reform Act (IRCA) of $1986^{4}$ found that undocumented immigrants had begun to earn significantly less than documented immigrants. While sometimes attributed to one's human capital (e.g., education, tenure, language) (Chiswick, 1984; Chiswick \& Miller, 1999) or macroeconomic fluctuations, recent studies have shown that increasing earnings differences between illegalized and legal immigrants is mainly driven by the implementation of increasingly restrictive policies towards immigrants and employers (Davila \& Pagan, 1997; Donato et al., 1992; Fry et al., 1995; Gomberg-Munoz \& Nussbaum-Barberena, 2011; Koussoudji \& Cobb-Clark, 1996; Kossoudji \& Cobb-Clark, 2000; Massey \& Bartley, 2005; Orrenius \& Zavodney, 2012; Pan, 2010; Phillips \& Massey, 1999; Powers et al., 1998; Rivera-Batiz, 1999; Taylor, 1992).

Although recent studies have shed new light on the reasons why illegalized immigrants earn less than legal immigrants, it is still important to examine the landmark studies of Chiswick (1984) and Chiswick and Miller (1999), as their work was the first to examine the effects of illegalized migrants on the labour market. This study will revisit their work to prevent any misunderstandings and misrepresentations of these studies, especially with respect to the link between illegalized immigrants' human capital and earnings. In his 1984 study, for example, Chiswick's research on earnings differences between Canadian/European illegal aliens, Caribbean illegal aliens, and Mexican illegal aliens led him to argue that differences were due to varying levels of human capital, including schooling and more labour market experience in the country of origin and/or the USA. However, the omission of legal immigrants in his sample prevented him from showing if and/or how human capital was rewarded differently for illegalized and legal immigrants —as is often the case between male and female groups, for example.

In a later study that explored the link between earnings, human capital, and time spent in the USA, Chiswick \& Miller's (1999) sample included only legalized migrants from the 1989 Legalized Population Survey (LPS). By examining a variety of factors such as education level, work experience, number of years since migration, and language proficiency, their model showed that individuals with proficient English skills earned more than those lacking in these skills: $8 \%$ more for women and $17 \%$ more for men. By excluding illegalized immigrants from their sample, however, their findings give the impression that human capital's link to earnings is the strongest indicator of labour market success, which prevents the model from showing the effect of illegality on earnings. Studies that have included factors indirectly related to illegality (e.g., industry type, apprehensions, employer sanctions) as well as illegality itself in their models, for example, have found these factors to have more of an impact on illegalized immigrants' earnings than human capital.

\footnotetext{
${ }^{4}$ In 1986, the United States passed IRCA to prevent Mexicans from crossing the border illegally into the United States. In addition to legalizing increased border enforcement, the Act provided a legal framework for employer sanction and providing amnesty.
} 
While examining the effects of the IRCA on the labour market conditions facing Mexican migrant workers, Donato et al. (1992) found the earnings gap between undocumented immigrants and legal immigrants to have increased after the implementation of the IRCA. Controlling for demographic, human capital, legal status, and family status factors, the researchers concluded that employers began to treat and evaluate undocumented migrants differently than legal immigrants. Lending support to this conclusion, Rivera-Batiz's (1999) analysis of the change in average hourly wages for undocumented migrants before/after legalization (from $\$ 6.90$ to $\$ 7.93$ for men and from $\$ 4.97$ to $\$ 6.00$ for women) showed that the change in legal status of illegal immigrants had stronger positive effects on their earnings than changes in schooling, English proficiency, and American work experience. Rivera-Batiz (1999) thus concluded that legalization might have eliminated the monopsonistic power that employers may exert over undocumented immigrants, granting them greater access to the labour market.

Phillips and Massey (1999) similarly concluded that a sizable wage penalty associated with illegal status emerged with the IRCA, finding that undocumented migrants subsequently earned $22 \%$ less than documented immigrants, despite controlling for background, human capital and labour market characteristics, among other variables. Mehta et al. (2002) also found undocumented status to negatively influence wages. After controlling for U.S. work experience, education, English proficiency, and occupation, undocumented Latin American men and women were found to earn $22 \%$ and $36 \%$ less than documented immigrant men and women counterparts (Mehta et al., 2002). While Mehta et al. (2002) were not able to determine the extent of the cause-and-effect relationship, the authors suggested that part of the difference in earnings between undocumented and documented migrants may be a result of wage penalties that seemed to be associated with employers' discriminatory practices. Yet part of the difference could also be due to undocumented workers' decisions to restrict their job search to lower-wage labour occupations to avoid apprehension by state authorities.

Lending partial support to Mehta et al.'s (2002) conclusion, studies have found that employers have shifted away from direct hiring to labour subcontracting as a result of IRCA's new "hiring fines" for employers who knowingly hire unauthorized workers, which also adversely affects undocumented immigrants' wages (Massey \& Bartley, 2005; Phillips \& Massey, 1999). Specifically, Massey \& Bartley (2005) found the IRCA to have changed labour market conditions from being favourable to immigrant assimilation in 1980, to creating labour market conditions that criminalized the hiring of undocumented immigrants by 1990. Before the IRCA, for example, undocumented immigrants were at risk of arrest and prosecution, while employers were exempt from these punitive measures (Massey \& Bartley, 2005). After 1986, however, the threat of sanctions for employers who hired undocumented migrants prompted employers to restructure their hiring process. This restructuring forced undocumented migrants to forfeit a portion of their wages to subcontractors for the opportunity to work in the USA (Orrenius \& Zavodny, 2012; Massey \& Bartley, 2005). 
Similarly, the enforcement of "paper work fines" ${ }^{5}$ through the IRCA was found to reduce the average wages of not only undocumented immigrants, but also all workers in organizations that report high expectations of receiving a paper work fine. To absorb the costs of paper work fines, employers reduced employees' earnings (Fry et al., 1995). Programs such as "No-Match letters" ${ }^{6}$ and expanded federal-local collaborations also facilitated the deterioration of undocumented immigrants' earnings. For instance, by increasing state presence at undocumented workers' job sites, this policy reduced the ability of undocumented immigrants to negotiate their working conditions (GombergMuoz \& Nussbaum-Barberena, 2011).

Within the limitations of these policies that criminalize the hiring of illegalized immigrants (Massey \& Bartley, 2005), some individuals have clear advantages over others. Compared to undocumented migrant women, for example, undocumented immigrant men reported higher earnings (Cobb-Clark \& Koussoudji, 1999; Mehta et al., 2002; Rivera-Batiz, 1999). Undocumented immigrants who speak English well also earn more than those who do not (Chiswick \& Miller, 1999; Mehta et al., 2002; Phillips \& Massey, 1999), and undocumented immigrants who obtained employment in higherpaying industries such as manufacturing earned more than those in the service and agricultural industry (Mehta et al., 2002). In addition, undocumented immigrants with access to specific forms of social capital, including friends and/or relatives, were found to earn more than undocumented immigrants without a social network (Aguilera \& Massey, 2003; Amuedo-Dorantes \& Mundra, 2007).

\section{Occupational Mobility}

In contrast to the number of studies on illegalized immigrants' earnings, few studies have examined their occupational mobility. Of these, illegalized immigrants were only found to experience occupational mobility within the lower segments of the labour market and/or in low-paying industries (Kossoudji \& Cobb-Clark, 1996, 2000; Powers \& Seltzer, 1998; Powers et al., 1998; Taylor, 1992). Similar to earnings, the crowding of illegalized immigrants into low-paying occupations was found to be largely due to recently implemented policies that restrict illegalized immigrants from being competitive with legal immigrants and/or native-borns.

After finding that unauthorized immigrants are less likely than legal immigrants to be employed in high-skill "primary" ${ }^{7}$ farm jobs, Taylor (1992) concluded that unauthorized status is a barrier to mobility into primary farm jobs in the post-IRCA era.

\footnotetext{
${ }^{5}$ Provisions in the IRCA empowered the Immigration and Naturalization Service (INS) to levy a "paperwork fine" on all employers who failed to verify and document the work authorization of new employee (Fry et al., 1995).

${ }^{6}$ Otherwise known as "Employer Correction Requests," the purpose of "No-Match Letters" are to help the Social Security Administration maintain correct records and to ensure that workers' earnings are credited toward their social security earnings record. The letters are sent to employers who reported more than 10 mismatched social security numbers (e.g., when the numbers do not match the name) (Gomberg-Munoz \& Nussbaum-Barberena, 2011).

${ }^{7}$ This study defines "primary" as supervisory, foreman, and machine operator jobs that require more firmspecific human capital than secondary (manual labour) jobs (Taylor, 1992, pg. 890).
} 
Although Koussoudji \& Cobb-Clark (1996) found unauthorized migrants to experience both upward and downward mobility in the USA's labour market after the IRCA was implemented, a more detailed analysis by Koussoudji \& Cobb-Clark (2000) found that these shifts took place within clustered traditional migrant occupations. Known as "occupational churning," this form of mobility is not assimilative in the traditional sense. Instead, it represents the workers' attempts to make the most of their opportunities within a well-defined and differently determined (often unauthorized) labour market (Koussoudji \& Cobb-Clark, 1996: 919). These findings are supported by Powers \& Seltzer (1998) and Powers et al. (1998) who also found undocumented immigrants' mobility to be concentrated to the lower half of the occupational status scores (limited to types of occupations in the agricultural and/or service industries). Davila \& Pagan (1997) further found that selected monitoring by the Immigration and Naturalization Service (INS) has redistributed workers from closely to weakly monitored industries, or more specifically, from the higher-paying manufacturing sector to the lower-paying agricultural sector (Davila \& Pagan, 1997).

As with earnings, some illegalized migrants were more likely to experience occupational mobility than others. Compared to women, male illegalized immigrants moved into a broader range of occupations than women over time. Often, women become locked into household jobs with little prospects for mobility (Powers et al., 1998). Having strong English skills was found to help Latino men experience upward mobility, whereas workers with less than adequate English skills were found to experience both upward and downward mobility (Kossoudji \& Cobb-Clark, 1996). Interestingly, increasing education while in the U.S. did not have any impact on mobility. For example, someone with a high school degree is no more likely to experience mobility than someone with no schooling, and formal credentials do not make a difference in the probability of mobility (Kossoudji \& Cobb-Clark, 1996). Illegalized migrants who stay continuously in the USA are also more likely to experience upward mobility than those who make multiple trips across the border, as they risk being apprehended without proper documentation (Kossoudji \& Cobb-Clark, 2000).

\section{The Effect of Illegalized Migrants on Native-borns Earnings}

Another approach that researchers have taken to determine the effect of illegalized immigrants on the labour market has been to examine their impact on the earnings of the native-born population (Bean et al., 1988; DeFreitas, 1988: Djajic, 1997; Sarris \& Zografakis, 1999). Focusing on labour markets in southwest USA, Bean et al.'s (1988) study found undocumented immigrants to positively affect the earnings of legal immigrants and native-borns. DeFreitas (1988) also found no discernible negative effect of illegal immigrants on employment, however, analyzing recent immigrants as a proxy for undocumented immigrants may have contaminated his findings. Djajic (1997) partially supports DeFreitas (1988) findings, determining that the presence of illegal immigrants positively affected the income of skilled native workers, but also showed that illegal immigrants could have a negative impact on the income of unskilled workers depending on whether natives were competing for the same jobs as undocumented immigrants (Djajic, 1997). More specifically, Djajic (1997) found that the presence of undocumented immigrants was not detrimental to native workers if the labour market was segmented and if undocumented migrants were employed in occupations that 
natives find unacceptable. Lending support to this conclusion, Sarris \& Zografakis' (1999) study of the impact of illegal immigration on the Greek economy found the inflow of illegal immigrants to result in the decline of incomes of households that are headed by an unskilled person (i.e., that are poor and middle income). Households that are headed by a skilled worker or pensioner, however, were found to benefit from illegal immigration (Sarris \& Zografakis, 1999).

\section{Employment Rates}

Examining the effect of illegalized immigrants on the employment rates of the nativeborn population, Mehta et al.'s (2002) study on the labour market experiences of undocumented migrants in Chicago found that their overall rates of unemployment were similar to the Chicago metro average (Mehta et al., 2002). Additional analysis between male and female undocumented immigrants, however, found that undocumented LatinAmerican women experience unemployment rates that approach $20 \%$, which is five times as high as the average of the remaining undocumented group (Mehta et al., 2002). While analyzing the effect of illegal immigrants on the employment of the nativeborn population in Italy, Venturini (1999) found that the increase of illegal units of labour produces a very small reduction in the use of legal labour. The competitive effect of illegal foreign workers is not homogenous, however, and is strongest in the agricultural sector (Venturini, 1999).

\section{The Effect of Illegalized Migrants on Social Welfare Systems}

Contesting allegations that illegalized immigrants are a drain on social welfare systems (Alcoba, 2013), most studies have found that undocumented immigrants contribute more than they receive at the national level, but receive more than they contribute at the regional and/or local levels. Grasmuck (1984), for example, concluded that the broader society benefits from undocumented Dominicans in New York City, who subsidize the state by means of tax and social security payments, yet have extremely low social service utilization rates compared to legal immigrant Dominicans. Specifically, she found that social security payments were deducted from $62 \%$ of undocumented Dominican workers and almost half filed a U.S. income tax form (Grasmuck, 1984). Lending support to Grasmuck's (1984) findings, Mehta et al. (2002) found that consumer expenditures of undocumented immigrants in the Chicago metro area generate more 31,000 jobs in the local economy and add $\$ 5.45$ billion annually to the gross regional product. Also, approximately $70 \%$ of undocumented workers pay taxes, although the vast majority do not receive benefits under government safety-net programs (Mehta et al., 2002).

Examining the effects of undocumented workers on the Minnesota economy, Kielkopf (2000) found that undocumented labour in selected industries accounts for between $\$ 1.56$ and $\$ 3.8$ billion of value added in the Minnesota economy annually. Kielkopf (2000) further found that undocumented labour accounts for approximately $2.4 \%$ of Minnesota's GDP and that undocumented migrants pay $\$ 1.02$ billion in taxes. Of this amount, $\$ 311$ million goes to social security and $\$ 354.4$ million goes to state and local taxes and fees. Kielkopf (2000) therefore concluded that undocumented immigrants provide a net gain to Minnesota taxpayers, rather than a net loss. 
While examining the impact of illegal immigrants in Texas and the USA, both Weintrub (1984) and Nadadur (2009) found the costs and benefits of undocumented immigrants on social welfare systems to vary according to national, state, and local levels. At the Texas state level, for example, Weintraub (1984) found the value of income taxes that undocumented persons pay to the state to exceed the value of public services such as education, health care, corrections, and welfare that they receive. Yet at the same time, six cities in the state of Texas spent more money providing services to undocumented aliens than they received in taxes (Weintraub, 1984). Lending partial support to Weintraub's (1984) findings, Nadadur (2009) concluded that undocumented immigrants positively impact the USA's economy while adversely imposing fiscal costs on state and local level economies.

\section{The Effect of Illegalized Immigrants on the Organizations They Work For}

While publicly available studies have not yet identified the profits that employers gain by paying illegalized immigrants less than native-borns or by crowding illegalized immigrants into low-paying occupations, they have identified a variety of other benefits that accrue to employers. Grasmuck (1984), Rivera-Batiz (1999), and Champlin \& Hake (2006) all concluded that one of the most important functions served by the illegal population is political, and resides in its vulnerability to employers, who can control them easily due to their lack of formal legal status (Grasmuck, 1984). Morales (1983-1984) similarly concluded that undocumented workers are preferable to TFWs during phases of rapid industrial transformation because their lack of legal protection prevents them from unionizing and/or protesting wage erosion. Illegalized immigrants' status also prevents them from competing for the same terms and conditions of employment that native-borns and legal immigrants have. Instead, they are tied to local employers, forced into accepting inequitable remuneration for their work and kept in low-paying occupations that native-borns would not accept (Donato et al., 1992; Gentsch \& Massey, 2012; Gomberg-Munoz \& Nussbaum-Barberena, 2011; Koussoudji \& CobbClark, 1996; Taylor, 1992). More specifically, De Genova (2002) recently argued that "the category 'illegal alien' is a profoundly useful and profitable one that effectively serves to create and sustain a legally vulnerable - and hence, relatively tractable and thus 'cheap'-reserve of labor" (p. 440). After reviewing the scholarship on 'migration' in relation to the nation-state, Bauder (2012) similarly concluded that "the distinction that nation-states create where otherwise no differences between people exist denies many migrants citizenship, status and/or rights and subsequently exposes them disproportionately to economic exploitation" (p. 57).

While studies have yet to identify the precise effect of illegalized immigrants on employers' profits, a review of the literature indicates that employers benefit from exploiting illegalized immigrants, despite the consequences for illegalized immigrants' labour market outcomes and thus the labour market(s) they participate in.

\section{Discussion \& Recommendations}

Compared to the number of studies that focused on illegalized immigrants and the labour market in an American context, very few published articles in English were available that examined the effect of illegalized immigrants on labour markets in a 
European or other context. Given this limitation, four main findings emerged from a review of the scholarship. First, the exploitation of illegalized immigrants was found to adversely affect their labour market outcomes more than their human capital or macroeconomic fluctuations. Second, the participation of illegalized immigrants in labour markets was found to positively affect the earnings of the native-born skilled workers, but adversely affect the earnings of the native-born unskilled population. Their effect on native-borns employment rates was found to be negligible overall. Third, illegalized immigrants' effect on the national-level social welfare system was found to be positive, while their effect on the state/provincial-level and local level social welfare systems was found to be positive in one case, and negative in others. Fourth, organizations were found to benefit from employing illegalized immigrants whose status renders them vulnerable to exploitation and unable to make demands for equitable remuneration.

Based on these findings, scholars made five main recommendations for improving the labour market outcomes of illegalized migrants and for equalizing the costs and benefits of illegalized migrants on local- and regional-level social welfare systems:

- Improve illegalized immigrants' human capital, including education and Englishlanguage skills (Chiswick, 1984; Chiswick \& Miller, 1999);

- Legalize or regularize illegalized immigrants or, similarly, create pathways to citizenship for illegalized immigrants (Standing Committee on Citizenship and Immigration, 2009; Suarez-Orozco, 2011);

- Re-allocate resources between federal, state/provincial, and local levels (Nadadur, 2009).

- Improve labour and workplace equity (Goldring \& Landolt, 2012; Suarez-Orozco et al., 2011); and

- Improve access to settlement services (Goldring \& Landolt, 2012; Martin et al., 2007; Suarez-Orozco et al., 2011).

These recommendations must also be preceded by a reversal of increasingly restrictive policies that illegalize immigrants, as well as the increasingly restrictive policies towards employers that encourage their exploitation of illegalized immigrants. As long as groups of immigrants remain illegalized, they constitute a group that is vulnerable to exploitation.

By excluding the effect of policies on illegalized immigrants' labour market outcomes in their model, Chiswick (1984) and Chiswick and Miller's (1999) findings led them to suggest that the improvement of illegalized immigrants' human capital would increase their earnings. However, studies that included policy factors in addition to human capital factors in their models found that the effect of human capital on illegalized immigrants earnings to be statistically insignificant, only explaining a small portion of the labour market outcomes between illegalized immigrants and legal immigrants (Davila \& Pagan, 1997; Donato et al., 1992; Fry et al., 1995; GombergMunoz \& Nussbaum-Barberena, 2011; Koussoudji \& Cobb-Clark, 1996; Kossoudji \& Cobb-Clark, 2000; Massey \& Bartley, 2005; Orrenius \& Zavodney, 2012; Pan, 2010; 
Phillips \& Massey, 1999; Powers et al., 1998; Rivera-Batiz, 1999; Taylor, 1992). Improving the human capital levels of illegalized immigrants without eliminating the restrictive immigration policies that have illegalized them, as well as the restrictive policies towards employers that encourage them to exploit illegalized immigrants, would therefore do little to improve their effect on the labour market. To address this issue, illegalized immigrants should be empowered through the removal of policies that exclude them and the creation of policies that include them. When there were very few (if any) restrictive policies towards immigrants without proper documentation in the USA during the 1980s, for example, immigrants without proper documentation had similar labour market outcomes to legal immigrants (Grasmuck, 1984; Massey, 1987).

Secondly, scholars have recommended granting legal status to illegalized immigrants, or at least creating pathways to citizenship. However, a review of the literature indicates that these initiatives are unlikely to succeed in improving illegalized immigrants' labour market outcomes (Standing Committee on Citizenship and Immigration, 2009; Suarez-Orozco et al., 2011). Legalizing has been found to improve the employment outcomes of highly skilled workers, but not necessarily the labour market of low-skilled workers (Kaushal, 2006; Lofstrom et al., 2010, 2012). Furthermore, although legalization through the IRCA provided labour market benefits to individuals who become legal, the enforcement policies that accompanied the IRCA led to decreased earnings and increased experiences of discrimination for immigrants who remained illegalized (Bansak \& Raphael, 2001; Glystos, 2005; Martin, 1994; Orrenius \& Zavodney, 2012; Philliips \& Massey, 1999). Therefore, a reversal of policies that illegalize immigrants would be a more effective strategy to improve their labour market outcomes than efforts to grant legal status to the illegalized.

Third, Nadadur's (2009) recommendation to efficiently re-allocate resources between federal, state/provincial, and local levels of government could also help the local and/or state/provincial economies. For example, by transferring the surplus that the federal government receives from collecting taxes from illegalized immigrants to the local and/or state/provincial levels, the deficit that local and state governments incur will disappear. Yet this re-allocation of funds only makes sense if illegalized migrants are given full access to the local and state/provincial resources and/or social welfare systems.

Fourth, scholars have recommended that labour and workplace equity policies be improved to include illegalized immigrants. Not only would these policies mandate employers to treat illegalized immigrants equitably, but they would also hold them accountable for doing so and would eliminate binding contracts between illegalized immigrants and their employers. These changes would give illegalized immigrants the freedom to be mobile, giving them the capacity to search for better employers if workplace conditions are poor. Putting the bargaining power back into illegalized immigrants' hands would vastly improve their labour market outcomes (Champlin \& Hake, 2006; Gomberg-Munoz \& Nussbaum-Barberena, 2011; Grasmuck, 1984). More specifically, in the absence of policies that illegalize immigrants as well as policies that encourage employers to exploit illegalized immigrants, recently legalized immigrants would have the capacity to negotiate for equitable remuneration, enabling them to contribute more to the labour market than they did as illegalized migrants. 
Finally, until illegalized immigrants are found to have equitable labour market outcomes and access to social welfare, federal, state/provincial, and local governments should work together to fund community-based organizations that provide illegalized immigrants with the resources they need to obtain equitable employment (Goldring \& Landolt, 2012; Martin et al., 2007; Suarez-Orozco et al., 2011).

\section{Conclusion}

In the past, national governments have often been guilty of implementing exclusionary immigration policies based on a subjective idea of who belongs in their country. Canada's 1885 Chinese Head Tax, the 1923 Chinese Exclusion Act, and the TFW program are only three such examples. Furthermore, organizations have often implemented a "divide and conquer" approach to management during periods of intensive competition in an attempt to increase their profits and stay competitive. A review of the literature on illegalized immigrants' labour market outcomes and access to social welfare indicates that these same practices are in effect today.

Contesting allegations that illegalized migrants adversely affect labour markets, the economic security of native-borns, and/or the social welfare systems of the countries they reside in, this paper showed that the development of policies that illegalize immigrants, as well as policies that facilitate the differential treatment of illegalized migrants, were found to adversely affect their labour market outcomes and thus the labour markets they participate in. This paper also found that the presence of illegalized immigrants in labour markets had a slightly positive, if not negligible effects on the economic security of native-borns, demonstrating that illegalized immigrants contribute more to the social welfare system than they benefit from it. In addition, organizations were found to benefit by actively exploiting illegalized immigrants through policies that restricted their labour market potential.

By creating inclusive policies rather than policies that illegalize immigrants, governments can begin to address this issue. By not creating a group of people vulnerable to exploitation based on their illegality, this group would no longer be available for employers to exploit. Instead, employers would be forced to remunerate them equitably, giving them the same chance as others to contribute to the labour markets in which they work.

\section{Acknowledgements}

I would like to thank RCIS, MCI and Ryerson University's Policy Studies Program for the fellowship opportunity that enabled me to explore this very important issue. I would also like to express my appreciation to members of the audience at the $2013 \mathrm{RCIS}$ Conference and the 2013 CSA Conference who provided me with excellent feedback. I would also like to thank Harald Bauder, Mehrunnisa Ali, Bryan Evans, Wendy Cukier, Farishta Dinshaw, Mehernosh Bomanji, Ann De Shalit and Nelson Palacio for their overall support and for inspiring me to think critically. 


\section{References}

Aguilera, M. B., \& Massey, D. S. 2003. "Social Capital and the Wages of Mexican Migrants: New Hypotheses Tests". Social Forces 82(2): 671-701.

Alcoba, N. 2013. "'Their First Stop is the Welfare Office': Bid to Improve Service Access for Illegal Workers Sparks Furious Toronto Council Debate". National Post. Retrieved from: http://news.nationalpost.com/2013/02/22/sanctuary-city-counciltakes-steps-to-help-undocumented-workers-feel-more-comfortable-accessingcity-services/

Allegro, L. 2010. 'Latino Migrations to the U.S. Heartland: 'Illegality,' State Controls, and Implications for Transborder Labor Rights". Latin American Perspectives 37(1): 172-184.

Amuedo-Dorantes, C., \& Mundra, K. 2007. "Social Networks and Their Impact on the Earnings of Mexican Migrants". Demography 44(4): 849-863.

Bansak, C., \& Raphael, S. 2001. "Immigration Reform and the Earnings of Latino Workers: Do Employer Sanctions Cause Discrimination”. Industrial and Labor Relations Review 54(2): 275-295.

Bauder, H. (2012). “Nation, 'migration' and critical practice”. Area 45(1): 56-62.

Bauder, H. 2013. "Why We Should Use the Term Illegalized Immigrant". RCIS Research Brief 2013/1. Retrieved from: http://www.ryerson.ca/rcis/publications/index.html

Bean, F. D., Lowell, B. L., \& Taylor, L. J. 1988. "Undocumented Mexican Immigrants and the Earnings of Other Workers in the United States". Demography 25(1): 3552.

Bernhard, J. K., Goldring, L., Young, J., Carolina, B., \& Wilson, B. 2007. "Living with Precarious Legal Status in Canada: Implications for the Well-being of Children and Families". Refuge 24(2): 101-114.

Blondell, J. 2008. "Adverse Impacts of Massive and Illegal Immigration in the United States". The Journal of Social, Political, and Economic Studies 33(3): 328-350.

Burgers, J. 1998. "In the Margin of the Welfare State: Labour Market Position and Housing Conditions of Undocumented Immigrants in Rotterdam". Urban Studies 35(10): 1855-1868.

Castles, S. 2004. "Why Migration Policies Fail". Ethnic and Racial Studies 27(2): 205227.

Champlin, D., \& Hake, E. 2006. "Immigration as Industrial Strategy in American Meatpacking". Review of Political Economy 18(1): 49-69.

Chiswick, B. R. 1984. "Illegal Aliens in the United States Labor Market: Analysis of Occupational Attainment and Earnings". International Migration Review 18(3): 714-732.

Chiswick, B. R., \& Miller, P. W. 1999. "Language skills and earnings among legalized aliens". Journal of Population Economics 12: 63-89. 
Cobb-Clark, D., \& Kossoudji, S. A. 1999. "Did Legalization Matter for Women? Amnesty and the Wage Determinants of Formerly Unauthorized Latina Workers". Gender Issues 17(4): 3-14.

Davila, A., \& Pagan, J. 1997. "The Effect of Selective INS Monitoring Strategies on the Industrial Employment Choice and Earnings of Recent Immigrants". Economic Inquiry 35: 138-150.

DeFreitas, G. 1988. "Hispanic Immigration and Labor Market Segmentation". Industrial Relations 27(2): 195-214.

De Genova, N. P. 2002. "Migrant 'lllegality' and Deportability in Everyday Life". Annual Review of Anthropology 31: 419-447.

Djajic, S. 1997. "Illegal Immigration and Resource Allocation". International Economic Review 38(1): 97-117.

Donato, K. M., Durand, J., \& Massey, D. S. 1992. "Changing Conditions in the US Labor Market: Effects of the Immigration Reform and Control Act of 1986". Population Research and Policy Review 11: 93-115

Foster, J. 2012. "Making Temporary Permanent: The Silent Transformation of the Temporary Foreign Worker Program". Just Labour: A Canadian Journal of Work and Society 19: 22-46.

Fry, R., Lowell, B. L., \& Haghighat, E. 1995. "The Impact of Employer Sanctions on Metropolitan Wage Rates". Industrial Relations 34(3): 464-484.

Gentsch, K. \& Massey, D. S. 2012. "Labor Market Outcomes for Legal Mexican Immigrants Under the New Regime of Immigration Enforcement". Social Science Quarterly 92(3): 875-893.

Glystos, N. P. 2005. "Stepping from Illegality to Legality and Advancing Towards Integration: The Case of Immigrants in Greece". The International Migration Review 29(4): 819-840.

Goldring, L., Berinstein, C., \& Bernhard, J. 2007. "Institutionalizing Precarious Immigration Status in Canada". CERIS Working Paper No. 61. Retrieved from: http://ceris.metropolis.net/Virtual\%20Library/WKPP\%20List/WKPP2007/CWP61. $\underline{\mathrm{pdf}}$

Goldring, L., \& Landolt, P. 2012. "The Impact of Precarious Legal Status on Immigrants' Economic Outcomes". IRPP. Retrieved from:

http://www.irpp.org/assets/research/diversity-immigration-and-integration/theimpact-of-precarious-legal-status-on-immigrants-economic-outcomes/IRPPStudy-no35.pdf

Goldring, L., \& Landolt, P. 2011. "Caught in the Work-Citizenship Matrix: The Lasting Effects of Precarious Legal Status on Work for Toronto Immigrants". Globalizations 8(3): 325-341.

Gomberg-Munoz, R., \& Nussbaum-Barberena, L. 2011. "Is Immigration Policy Labor Policy?: Immigration Enforcement, Undocumented Workers, and the State". Human Organization 70(4): 366-375. 
Gonzales, R. G. 2011. "Learning to be Illegal: Undocumented Youth and Shifting Legal Contexts in the Transition to Adulthood". American Sociological Review 76(4): 602-619.

Grasmuck, S. 1984. "Immigration, Ethnic Stratification, and Native Working Class Discipline: Comparisons of Documented and Undocumented Dominicans". International Migration Review 18(3): 692-713.

Jimenez, M. 2003. "200,000 Illegal Immigrants Toiling in Canada's Underground Economy". The Globe and Mail. A1.

Kaushal, N. 2006. "Amnesty Programs and the Labor Market Outcomes of Undocumented Workers". The Journal of Human Resources XLI: 631-647.

Keung, N. 2013. "Toronto Declared 'Sanctuary City' to Non-status Migrants". Toronto Star. Retrieved from: http://www.thestar.com/news/gta/2013/02/21/cisanctuarycity21.html

Khandor, E., McDonald, J., Nyers, P., \& Wright, C. 2004. "The Regularization of NonStatus Immigrants in Canada, 1960-2004". Retrieved from: http://accessalliance.ca/sites/accessalliance/files/documents/3.5.1\%20\&\%206\%20Regularization\%20Report.pdf

Kielkopf, J. J. 2000. "The Economic Impact of Undocumented Workers in Minnesota". HACER. Retrieved from: http://www.macalester.edu/courses/econ108/hacer.pdf

Kossoudji, S., \& Cobb-Clark, D. A. 1996. "Finding Good Opportunities Within Unauthorized Markets: U.S. Occupational Mobility for Male Latino Workers". The International Migration Review 30(4): 901-924.

Koussoudji, S. A., \& Cobb-Clark, D. A. 2000. "IRCA's Impact on the Occupational Concentration and Mobility of Newly-Legalized Mexican Men". Journal of Population Economics 13: 81-98.

Linklater, L. 2008. "Director General, Immigration Branch, Department of Citizenship and Immigration". Committee Evidence, Meeting No. 13, 15:50.

Lofstrom, M., Hill, L., \& Hayes, J. 2010. "Did Employer Sanctions Lose Their Bite? Labor Market Effects of Immigrant Legalization". Public Policy Institute of California. Retrieved from: http://ftp.iza.org/dp4972.pdf

Lofstrom, M., Hill, L., \& Hayes, J. 2012. "Wage and Mobility Effects of Legalization: Evidence from the New Immigrant Survey". Journal of Regional Science 00(00): 1-27.

Lyon, B. 2003-2004. 'When More 'Security' Equals Less Workplace Safety: Reconsidering U.S. Laws that Disadvantage Unauthorized Workers". Labor \& Employment 6(3): 571-611.

Magalhaes, L., Carrasco, C., \& Gastaldo, D. 2010. "Undocumented Migrants in Canada: A Scope Literature Review on Health, Access to Services \& Working Conditions". Journal of Immigrant Minority Health 12: 132-151. 
Marsden, S. 2012. "The New Precariousness: Temporary Migrants and the Law in Canada". Canadian Journal of Law and Society 27(2): 209-229.

Martin, N., Morales, S., \& Theodore, N. 2007. "Migrant Worker Centres: Contending with Downgrading in the Low-wage Labor Market". GeoJournal 68: 155-165.

Martin, P. 1994. "Good Intentions Gone Awry: IRCA and U.S. Agriculture". American Academy of Political Social Science 534: 44-57.

Massey, D. S. 1987. "Do Undocumented Migrants Earn Lower Wages than Legal Immigrants? New Evidence from Mexico". International Migration Review 21(2): 236-274.

Massey, D. S., \& Bartley, K. 2005. "The Changing Legal Status Distribution of Immigrants: A Caution". International Migration Review 2: 469-484.

McDowell, L., Batnitzky, A., \& Dyer, S. 2009. "Precarious Work and Economic Migration: Emerging Immigrant Divisions of Labour in Greater London's Service Sector". International Journal of Urban and Regional Research 33(1): 3-25.

McQuillon, K. 2013. "All the Workers We Need: Debunking Canada's Labour Shortage Fallacy". The School of Public Policy SPP Research Papers 6(16). Retrieved from: http://policyschool.ucalgary.ca/sites/default/files/research/mcquillan-labourshortages-final.pdf

Mehta, C., Theodore, N., Mora, I., \& Wade, J. 2002. “Chicago's Undocumented Immigrants: An Analysis of Wages, Working Conditions, and Economic Contributions". Retrieved from: http://www.williamperezphd.com/articles/mehtatheodore-mora-wade-2002.pdf

Miklavcic, A. 2011. "Canada's Non-status Immigrants: Negotiating Access to Health Care and Citizenship". Medical Anthropology 30(5): 496-597.

Morales, R. 1983-1984. "Transitional Labor: Undocumented Workers in the Los Angeles Automobile Industry". International Migration Review 17(4): 570-596.

Nadadur, R. 2009. "Illegal Immigration: A Positive Economic Contribution to the United States". Journal of Ethnic and Migration Studies 35(6): 1037-1052.

Orrenius, P. M., \& Zavodny, M. 2012. "The Economic Consequences of Amnesty for Unauthorized Immigrants". Cato Journal 32(1): 85-106.

Pan, Y. 2010. "The Impact of Legal Status on Immigrants' Earnings and Human Capital: Evidence from the IRCA 1986". Department of Economics Working Paper 201002. Retrieved from: http://bus.Isu.edu/McMillin/Working Papers/pap10 02.pdf

Passel, J., \& Cohn, D. 2006. "Unauthorized Immigrants: 11.1 Million in 2011". PewResearch Hispanic Trends Project. Retrieved from: http://www.pewhispanic.org/2012/12/06/unauthorized-immigrants-11-1-million-in$\underline{2011 /}$

Paraskevopoulou, A. 2011. "Undocumented Worker Transitions: Family Migration”. International Journal of Sociology and Social Policy 31(1/2): 110-122. 
Phillips, J. A., \& Massey, D. S. 1999. "The New Labor Market: Immigrants and Wages after IRCA". Demography 36(2): 233-246.

Powers, M. G., \& Seltzer, W. 1998. "Occupational Status and Mobility Among Undocumented Immigrants by Gender". The International Migration Review 32(1): 21-55.

Powers, M. G., Seltzer, W., \& Shi, J. 1998. "Gender Differences in the Occupational Status of Undocumented Immigrants in the United States: Experience Before and After Legalization". The International Migration Review 32(4): 1015-1046.

Reksten, T. 1991. The Dunsmuir Saga. Vancouver: Douglas \& Mclntyre.

Rivera-Batiz, F. 1999. "Undocumented Workers in the Labour Market: An Analysis of the Earnings of Legal and Illegal Mexican Immigrants in the United States". Journal of Population Economics 12: 91-116.

Roy, P. E. 1989. A White Man's Province. Vancouver: The University of British Columbia Press.

Sarris, A. H., \& Zografakis, S. 1999. "A Computable General Equilibrium Assessment of the Impact of Illegal Immigration on the Greek Economy". Journal of Population Economics 12: 155-182.

Sharma, N. 2006. Home Economics: Nationalism and the Making of 'Migrant Workers' in Canada. Toronto: University of Toronto Press Incorporated.

Simich, L., Wu, F., \& Nerad, S. 2007. "Status and Health Security: An Exploratory Study of Irregular Immigrants in Toronto". Canadian Journal of Public Health 98(5): 369373.

Standing Committee on Citizenship and Immigration. 2009. "Temporary Foreign Workers and Non-Status Workers". House of Commons. Retrieved from: http://ufcw.ca/Theme/UFCW/files/PDF\%202009/TEMPFO 1.PDF

Suarez-Orozco, C., Yoshikawa, H., Teranishi, R., \& Suarez-Orozco, M. 2011. "Growing Up in the Shadows: The Developmental Implications of Unauthorized Status". Harvard Educational Review 81(3): 438-620.

Taylor, J. E. 1992. "Earnings and Mobility of Legal and Illegal Immigrant Workers in Agriculture". American Journal of Agricultural Economics 74(4): 889-896.

Tomlinson, K. 2013. "RBC Replaces Canadian Staff with Foreign Workers". CBC. Retrieved from: http://www.cbc.ca/news/canada/britishcolumbia/story/2013/04/05/bc-rbc-foreign-workers.html

Venturini, A. 1999. "Do Immigrants Working Illegally Reduce the Natives' Legal Employment? Evidence From Italy". Journal of Population Economics 12: 135154.

Villarejo, D. 2003. "The Health of U.S. Hired Farm Workers". Annual Review of Public Health 24: 175-193.

Walia, H. 2012. "Transient Servitude: Migrant Labour in Canada and the Apartheid of Citizenship". Race \& Class 52(1): 71-84. 
Weintraub, S. 1984. "Illegal Immigrants in Texas: Impact on Social Services and Related Considerations". International Migration Review 18(3): 733-747.

Wright, C. 2003. "Moments of Emergence: Organizing by and with Undocumented and Non-Citizen People in Canada After September 11". Refuge 21(3): 5-15. 